organisms colonising the wound and also, perhaps, with the natural defences.

Clinical sensitivity tests are required to give information on the possible effectiveness of treatment with an antibiotic, and for this purpose 18-hour diffusion tests with flucloxacillin at $37^{\circ} \mathrm{C}$ might be adequate. These would also detect the emergence of strains of Staph aureus highly resistant to flucloxacillin at $37^{\circ} \mathrm{C}$-a type of resistance which we have not yet encountered but for which the microbiologist must be vigilant. Benner and Kayser" ${ }^{11}$ found an increasing proportion of clinical isolates of Staph aureus in which most cells in the culture were resistant to methicillin and its analogues, and infection with such strains was less responsive to treatment with these antibiotics. The heteroresistant state is best shown by parallel sensitivity tests with methicillin at $30^{\circ} \mathrm{C}$ and at $37^{\circ} \mathrm{C}$, or by 18 - and 42 -hour methicillin sensitivity tests at $37^{\circ} \mathrm{C}$, which would also show the reduced sensitivity of these strains at $37^{\circ} \mathrm{C}$ and detect the emergence of a strain highly resistant at $37^{\circ} \mathrm{C}$. Methicillin sensitivity tests done only at $30^{\circ} \mathrm{C}$ would fail to detect the emergence of such highly resistant strains, as well as failing to recognise the potential value of flucloxacillin and its analogues in treatment of infections by heteroresistant strains of Staph aureus.
We thank Mr D M Jackson and the staff of the burns unit for their co-operation.

\section{References}

${ }^{1}$ Annear, D I, Medical fournal of Australia, 1968, 1, 444.

2 Dyke, K G H, fournal of Medical Microbiology, 1969, 2, 261.

3 Rolinson, G N, British Medical fournal, 1961, 1, 125.

- Knox, R, British Medical fournal, 1961, 1, 126.

5 Chabbert, Y A, et al, Revue Française d'Etudes Cliniques et Biologiques, 1965, $10,495$.

${ }^{6}$ Hewitt, J H, Coe, A W, and Parker, M T, fournal of Medical Microbiology, $1969,2,443$.

7 Ayliffe, G A J, et al, fournal of Clinical Pathology, 1977, 30, 40.

${ }^{8}$ Lowbury, E J L, et al, Lancet, 1961, 1, 1318.

${ }^{9}$ Lowbury, E J L, and Miller, R W S, Lancet, 1962, 2, 640.

10 Lowbury, E J L, British Medical fournal, 1960, 1, 994.

1 Benner, E J, and Kayser, F H, Lancet, 1968, 2, 741.

12 Parker, M T, and Hewitt, J H, Lancet 1970, 1, 800.

13 Siboni, K, and Poulsen, E D, Danish Medical Bulletin, 1968, 15, 161.

${ }^{14}$ Bulger, R J, Feigl, P, and Nielson, K, Fournal of Infectious Diseases, 1972, $126,674$.

${ }^{15}$ Ayliffe, G A J, Andrews, J, and Williams, J D, Lancet, 1974, 1, 573.

${ }^{16}$ Lacey, R W, Fournal of Clinical Pathology, 1973, 26, 899.

17 Sutherland, R, and Rolinson, G N, fournal of Bacteriology, 1964, 87, 887.

(Accepted 22 February 1977)

\title{
A small cluster of Hodgkin's disease
}

\author{
A R EVANS, B W HANCOCK, M J BROWN, J RICHMOND
}

British Medical fournal, 1977, 1, 1056-1057

\section{Summary}

Nine cases of Hodgkin's disease and one of acute lymphoblastic leukaemia occurred in 1972-5 in an area of less than $1 \mathrm{~km}^{2}$. Clinical, social, and drug histories provided no relevant information, and definite patient-to-patient contacts before the onset of disease were not established. There was a higher incidence of malignant neoplasms in first-degree relatives of the patients than in those of a small control group living in the same area. There was no apparent reason for this cluster of cases, but geographical, climatic, and entomological studies are being carried out.

\section{Introduction}

Reports of cases of Hodgkin's disease ${ }^{1-4}$ and leukaemia ${ }^{5-7}$ occurring in a pattern similar to that seen in infectious disease have stimulated interest in space-time clustering in all types of

Sheffield Area Health Authority

A R EVANS, DOBSTRCOG, MRCGP, general practitioner

Department of Haematology, Northern General Hospital, Sheffield S5 7AU

M J BROWN, MB, MRCPATH, consultant haematologist

University Department of Medicine, Royal Hospital, Sheffield S1 3SR B W HANCOCK, DCH, MRCP, lecturer

J RICHMOND, MD, FRCP, professor lymphoreticular and haematological malignancies. We recently heard about a cluster of five patients with Hodgkin's disease living close to each other, and further investigation disclosed a further four cases of Hodgkin's disease and one of leukaemia within an area of less than $1 \mathrm{~km}^{2}$ (population about 2800). All these patients presented within a period of four years. We describe here the clinical and epidemiological findings.

\section{Patients and methods}

Full clinical and histological details were available for all 10 patients. All were interviewed and epidemiological inquiries made. The immune status of four patients was assessed by in-vivo and in-vitro techniques.

\section{Results}

The incidence of Hodgkin's disease in the area studied was greater than 70 cases per 100000 population per year, although the expected incidence (for the Sheffield metropolitan area) was 4-5 cases per 100000 per year. The clinical and epidemiological details of the patients are summarised in the table and their homes are marked on the map. For reasons of confidentiality we have not given precise details of roadways.

The patients had no common features in their medical histories, and the incidence of glandular fever, tonsillectomy, and appendicectomy was not increased. The drug and social histories of the patients were unremarkable but the incidence of malignant neoplasms among first-degree relatives seemed to be higher than in a group of 30 patients matched for age and sex who were attending the local general practitioner's surgery. Among first-degree relatives of the controls there were seven malignant neoplasms (three gastrointestinal, two lung, one haematological, and one where the primary site was undetermined), while among those of the 10 patients studied there were six (four gastrointestinal, one lung, and one haematological).

No definite patient-to-patient contacts were elicited, despite the fact that several of the patients lived very near to one another. No 
Summary of clinical findings in cluster of cases

\begin{tabular}{|c|c|c|c|c|c|c|c|c|c|c|c|}
\hline $\begin{array}{l}\text { Case } \\
\text { No }\end{array}$ & $\begin{array}{l}\text { Age } \\
\text { and } \\
\text { sex }\end{array}$ & Occupation & $\begin{array}{l}\text { Date of } \\
\text { arrival } \\
\text { in area }\end{array}$ & $\begin{array}{c}\text { Date of } \\
\text { presentation }\end{array}$ & Medical history & $\begin{array}{l}\text { Family history } \\
\text { of malignancy }\end{array}$ & $\begin{array}{c}\text { Lymph node } \\
\text { site of } \\
\text { presentation }\end{array}$ & $\begin{array}{l}\text { Ann } \\
\text { Arbor } \\
\text { stage }\end{array}$ & $\begin{array}{l}\text { Type of } \\
\text { Hodgkin's } \\
\text { disease }\end{array}$ & Immunity & Fate \\
\hline 1 & $10 \mathrm{M}$ & Schoolboy & 1969 & Jan 1972 & Tonsillectomy 1969 & Leukaemi & & & (Acute lympho- & & Remission \\
\hline 2 & $29 M$ & Milkman & 1971 & Nov 1972 & Scarlet fever in childhood & $\begin{array}{l}\text { (grandmother) } \\
\text { Stomach carcinoma } \\
\text { (father) }\end{array}$ & Axilla & 3B & $\begin{array}{c}\text { cytic letukaemia) } \\
\text { Nodular } \\
\text { sclerosing }\end{array}$ & & Remission \\
\hline 3 & $54 \mathrm{~F}$ & Clerk & 1969 & Aug 1973 & Herpes zoster 1973 & Rectal carcinoma & Cervical & $4 \mathrm{~A}$ & Mixed cell & & Died 1973 \\
\hline 4 & $22 \mathrm{M}$ & Electrician & 1969 & Nov 1973 & $\begin{array}{l}\text { Glandular fever 1967, } \\
\text { eczema and hayfever in }\end{array}$ & & Cervical & $1 \mathrm{~A}$ & Mixed cell & Normal & Remission \\
\hline 5 & $60 \mathrm{M}$ & Labourer & 1960 & July 1974 & $\begin{array}{c}\text { childhood } \\
\text { Eczema in youth, chronic } \\
\text { parotitis } 1956 \text { (radiotherapy), } \\
\text { duodenal ulcer } 1958\end{array}$ & & Cervical & $3 \mathrm{~A}$ & Mixed cell & Normal & Died 1975 \\
\hline 6 & $27 \mathrm{~F}$ & Housewife & 1974 & Jan 1975 & & Eye tumour & Cervical & $4 B$ & $\begin{array}{l}\text { Lymphocyte } \\
\text { depleted }\end{array}$ & & $\begin{array}{l}\text { Alive in } \\
\text { relapse }\end{array}$ \\
\hline 7 & $24 \mathrm{~F}$ & $\begin{array}{l}\text { Computer } \\
\text { programmer }\end{array}$ & 1971 & Jan 1975 & $\begin{array}{l}\text { Recurrent tonsillitis over } \\
\text { previous } 5 \text { years }\end{array}$ & & Cervical & $2 \mathrm{~A}$ & $\begin{array}{l}\text { Lymphocyte } \\
\text { depleted }\end{array}$ & Normal & Remission \\
\hline 8 & $45 \mathrm{~F}$ & Canteen assistant & 1958 & April 1975 & $\begin{array}{c}\text { Duodenal ulcer } 1960 \text {, } \\
\text { dermatitis } 1971\end{array}$ & $\begin{array}{c}\text { Abdominal neoplasm } \\
\text { (father) }\end{array}$ & & 3B & $\begin{array}{l}\text { Lymphocyte } \\
\text { predominant }\end{array}$ & . & Remission \\
\hline $\begin{array}{r}9 \\
10\end{array}$ & $\begin{array}{l}38 M \\
64 M\end{array}$ & $\begin{array}{l}\text { Driving instructor } \\
\text { Excavator driver }\end{array}$ & $\begin{array}{l}1970 \\
1936\end{array}$ & $\begin{array}{l}\text { Oct } 1975 \\
\text { Dec } 1975\end{array}$ & $\begin{array}{l}\text { Tonsillectomy } 1944 \\
\text { Appendicectomy in } \\
\text { childhood }\end{array}$ & $\begin{array}{c}\text { Stomach carcinoma } \\
\text { (grandmother) }\end{array}$ & $\begin{array}{l}\text { Mediastinal } \\
\text { Abdominal }\end{array}$ & $\begin{array}{l}2 \mathrm{~A} \\
2 \mathrm{~B}\end{array}$ & $\begin{array}{l}\text { Mixed cell } \\
\text { Lymphocyte } \\
\text { predominant }\end{array}$ & Normal & $\begin{array}{l}\text { Remission } \\
\text { Remission }\end{array}$ \\
\hline
\end{tabular}

contacts common to the patients before the onset of disease-for example, tradesmen, clergymen, medical practitioners-were detected. Six of the patients lived in houses built within the last seven years on old farm land. All but one patient lived on one side of a valley, along which runs a brook (see map). On the other side of the brook is a smal factory but no definite pollution from this has been detected in the past 10 years. The brook is polluted mainly from surface drains, as are many other streams, and it has been known for several years that sewage overflows into the brook in wet weather. The main sewerage services to the new estate have recently been found to be inadequate.

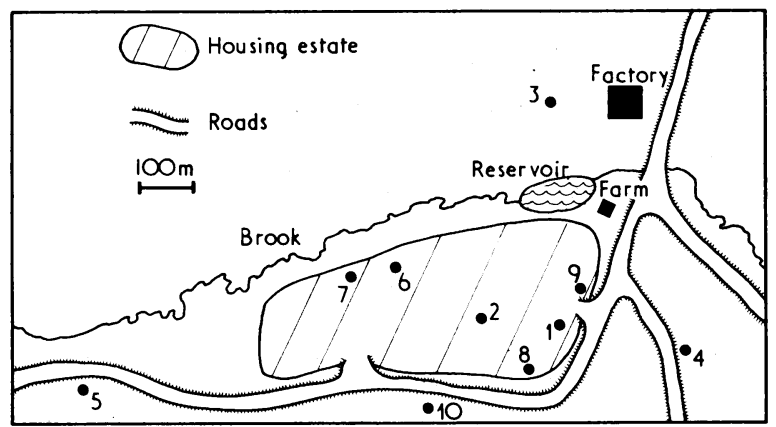

Map showing homes of the 10 patients in the cluster with relevant geographical and environmental features. area are being investigated further. A medical history of glandular fever ${ }^{11}$ and tonsillectomy ${ }^{12}$ or appendicectomy ${ }^{13}$ may be associated with an increased incidence of Hodgkin's disease, but these antecedent factors were not found in most of our patients.

A possible genetic role in leukaemia and lymphoma is suggested by $(a)$ the familial clustering of some cases, ${ }^{14-16}(b)$ the finding of an increased prevalence of certain HLA antigens, ${ }^{17}$ and $(c)$ an association with genetically determined immunological abnormalities. ${ }^{18}$ None of our patients were related and immune status was normal in those patients tested. There was, however, an increased incidence of malignant neoplasms in the close relatives of the patients when compared with that in the relatives of a small group of age- and sex-matched controls on the same general practice list and living in the same area.

The "incubation period" in Hodgkin's disease has been variously calculated as being from a few months ${ }^{19}$ to several years. ${ }^{1}=4$ Our study gives no definite information on this point, but if we are dealing with an infectious agent and assuming the earliest date of possible contact within the cluster to be 1971 the incubation period here seems to be less than five years.

We thank Mrs $\mathbf{P}$ Wild, Mrs $M$ Byram, Dr J $\mathrm{R}$ Horn, Dr $\mathrm{H} J$ Dooley, Dr K C A Y Baldwin, Dr W G Cautley, Dr M H G Waddington, Dr H M Halle, and Dr F C Armstrong for their help and cooperation.

We are grateful to the consultant medical staff of Weston Park Hospital for access to their patients.

\section{References} the brook, a fact only recently discovered during a predemolition survey of the farm buildings.

Climatic indices from official meterological office statistics show that the area had a wet spring and prolonged dry summer in 1969 and 1970. These years may be important in the history of the cluster, because most of the patients arrived in the area during. or shortly after that time. The local incidence of notifiable disease for the period of study was unremarkable.

\section{Discussion}

The problem in establishing the statistical significance of clusters has been discussed elsewhere. ${ }^{8}$ Nevertheless, the patients we studied lived in a very small area and the incidence during the period of observation was about 15 times that seen in the rest of the city.

Unlike previous investigators, ${ }^{4}{ }^{10}$ we were unable to establish any definite prior contact between the patients in our study. Clinical, social, and drug histories did not seem to be relevant, but the geographical, climatic, and entomological features of the
1 Vianna, N J, Greenwald, P, and Davies, J N P, Lancet, 1971, 1, 1209.

2 Vianna, N J, et al, Annals of Internal Medicine, 1972, 77, 169.

3 Alderson, M R, and Nayak, R, fournal of Chronic Diseases, 1972, 25, 253.

4 Vianna, N J, and Polan, A K, New England fournal of Medicine, 1973, 289, 499.

5 Wood, E E, British Medical fournal, 1960, 1, 1760.

${ }^{6}$ Powell, D E B, Lancet, 1971, 2, 350.

${ }^{7}$ Heath, C W, and Hasterlik, R J, American Fournal of Medicine, 1963, 34, 796.

8 British Medical fournal, 1975, 1, 351.

${ }^{9}$ Klinger, R J, and Minton, J P, Lancet, 1973, 1, 168.

11 Rosdahl, N, Larsen, S O, and Clemmesen, J, British Medical fournal, $1974,2,253$.

12 Vianna, N J, Greenwald, P, and Davies, J N P, Lancet, 1971, 1, 431

${ }^{13}$ Bierman, H R, Cancer, 1968, 21, 109.

14 Rigby, P G, et al, Archives of Internal Medicine, 1968, 121, 67.

15. Vianna, N J, et al, Lancet, 1974, $2,854$.

${ }_{16}$ Kyle, R A, et al, Cancer, 1976, 37, 1496.

17 Zervase, J D, Delamore, I W, and Israels, M C G, Lancet, 1970, 2, 634.

18 Poltosky, A I, et al, American fournal of Medicine, 1971, 50, 42

19 Wagener, D J T, and Haanen, G, Lancet, 1975, 2, 747.
10 Schimpff, S C, et al, Lancet, 1975, 1, 124. 